\title{
FAKTOR PENGHAMBAT PEMENUHAN HAK PENDIDIKAN DISABILITAS DI KOTA AMBON
}

\author{
Maslan Abdin*, Johanes M. Tetelepta \\ Politeknik Negeri Ambon, Maluku, Indonesia \\ *maslanabdin15@gmail.com
}

\begin{abstract}
People with disabilities in Ambon City are part of the citizens who must be given the right to education in a fair and non-discriminatory manner by upholding human rights. Obstacle factors in the fulfilment of education will certainly exist. The government as the executor of the constitution is responsible for efforts to resolve it. This study uses a qualitative research design with a case study method. The subjects in this study are schools, parents and the Ambon city government. The results of the identification and analysis found that the factors that hindered the fulfilment of education for persons with disabilities in the city of Ambon, among others (1) parents of students, among others, parents still feel ashamed of the condition of their children, busy parents and access to special schools that are far away. (2) Inadequate school facilities and infrastructure according to the individual needs of each child with disabilities. (3) Only 23\% of the accompanying teachers have special education qualifications from the total number of accompanying teachers, namely 116 teachers. On average, the accompanying teachers are classroom teachers and subject teachers with non-special needs education qualifications.
\end{abstract}

Keywords: barrier factors, education rights, persons with disabilities.

\begin{abstract}
Abstrak
Penyandang disabilitas di Kota Ambon menjadi bagian dari warga Negara yang harus diberikan hak pendidikannya secara berkeadilan serta tidak diskriminatif dengan menjunjung tinggi hak asasi manusia. Faktor kendala dalam pemenuhan pendidikan pasti akan ada. Pemerintah sebagai pelaksana konstitusi bertanggung jawab dalam upaya penyelesaiannya. Penelitian ini menggunakan desain penelitian kualitatif dengan metode studi kasus, Subjek dalam penelitian ini yaitu sekolah, orang tua dan pemerintah kota ambon. Hasil identifikasi dan analisis menemukan bahwa faktor kendala dalam pemenuhan pendidikan bagi penyandang disabilitas di kota Ambon antara lain (1) orang tua siswa antara lain orang tua masih merasa malu dengan keadaan anak, kesibukan orang tua dan akses ke sekolah luar biasa yang jauh. (2) Sarana dan prasarana sekolah yang kurang memadai sesuai kebutuhan individu masing-masing anak disabilitas. (3) Guru pendamping 23\% saja yang berkualifikasi pendidikan khusus dari jumlah keseluruhan guru pendamping yaitu 116 guru. Ratarata guru pendamping adalah guru kelas dan guru mapel dengan tamatan bukan berkualifikasi pendidikan kebutuhan khusus.
\end{abstract}

Kata kunci: faktor hambatan; hak pendidikan; penyandang disabilitas 


\section{PENDAHULUAN}

Majelis Umum Perserikatan Bangsa-Bangsa telah mengeluarkan Resolusi Nomor A/61/106 tentang Convention on the Rights of Persons with Disabilities. Resolusi tersebut memuat hak-hak penyandang disabilitas dan mengatur langkah-langkah untuk menjamin pelaksanaan konvensi tersebut. Mengingat pentingnya penghormatan, perlindungan, pemenuhan, dan memajukan HAM penyandang disabilitas, pemerintah Indonesia pun menandatangani Resolusi pada tanggal 30 Maret 2007 di New York (Basuki, 2012).

Pada tahun 1997, Indonesia mengeluarkan Undang-Undang Nomor 4 Tahun 1997 tentang Penyandang Cacat. Kemudian pada 2016, Indonesia kembali mengganti undangundang yang berkaitan dengan penyandang cacat dengan penyandang disabilitas melalui Undang-Undang Republik Indonesia Nomor 8 Tahun 2016 tentang Penyandang Disabilias (Itasari, 2020) yang menyatakan bahwa penyandang disabilitas adalah setiap orang yang mengalami keterbatasan fisik, intelektual, mental, dan/atau sensori dalam jangka waktu lama yang dalam berinteraksi dengan lingkungan dapat mengalami hambatan dan kesulitan untuk berpartisipasi secara penuh dan efektif dengan warga negara lainnya berdasarkan kesamaan hak (Santoso \& Apsari, 2017).

Pentingnya penekanan perlindungan hak bagi penyandang disabilitas dikarenakan penyandang disabilitas merupakan orang-orang yang berkemampuan khusus, sehingga perlu perlakuan yang khusus juga dari pemerintah untuk memenuhi hak-hak yang disebutkan dalam Bab XA UUD NRI 1945 mengenai hak asasi manusia. Selain itu tanpa adanya perlindungan lebih dari Pemerintah, para kaum penyandang disabilitas ini rentan terhadap perlakuan diskriminasi, terlebih terhadap pemenuhan hak-haknya (Widinarsih, 2017).

Penyandang disabilitas sekalipun tidak disebut secara tegas dalam UUD NRI tahun 1945, namun merupakan bagian dari manusia yang kedudukannya sama. Sebagaimana prinsip dalam HAM yang universal, non diskriminasi, tidak dapat dipungkiri, tidak dapat dibagi dan tidak dapat dikurangi. Pemenuhan hak perlu adanya payung hukum, hal ini selaras dengan tujuan pembentukan negara yang tertuang dalam Pembukaan UUD NRI 1945 "memajukan kesejahteraan umum, mencerdaskan kehidupan bangsa, mewujudkan keadilan sosial bagi seluruh rakyat Indonesia". Pada intinya bahwa perwujudan nya bagi seluruh rakyat Indonesia tanpa pandang bulu. Baik manusia yang terlahir "normal" dan terlahir dengan "ketidaksempurnaan fisik atau mental" (Pawestri, 2017).

Dalam konteks pendidikan negara indonesia menjamin hak pendidikan bagi warga negara hal ini secara eksplisit dituangkan dalam Undang-Undang Dasar Negara Kesatuan Republik Indonesia Tahun 1945 (UUD NRI Tahun 1945) dan peraturan pelaksananya. Pasal 31 dalam UUD NRI Tahun 1945 tersirat bahwa setiap warga negara berhak mendapat pendidikan. Selanjutnya pada Pasal 28C Ayat (1) dan Pasal 28E Ayat 1 UUD NRI Tahun 1945 memberikan jaminan untuk setiap warga negara mendapatkan pendidikan yang layak. Dipertegas pada Pasal 31 Ayat (2) UUD NRI Tahun 1945 yang menegaskan bahwa setiap warga negara wajib mengikuti pendidikan dasar dan pemerintah wajib membiayainya. Hal ini didukung dengan aturan pelaksana UndangUndang Republik Indonesia Nomor 20 Tahun 2003 tentang Sistem Pendidikan Nasional (UU Sisdiknas) yang menjelaskan bahwa setiap warga negara mempunyai hak yang sama untuk mendapatkan pendidikan yang berkualitas.

\section{JURNAL KEWARGANEGARAAN}


Di samping beberapa undang-undang di atas, pengaturan mengenai hak pendidikan penyandang disabilitas telah diatur dalam Undang-Undang Republik Indonesia Nomor 8 Tahun 2016 tentang Penyandang Disabilias (UU No. 8 Tahun 2016). 8 Pasal 10 UU No. 8 Tahun 2016 menentukan bahwa hak pendidikan untuk penyandang disabilitas meliputi hak untuk: (1) mendapatkan pendidikan yang bermutu pada satuan pendidikan di semua jenis, jalur, dan jenjang pendidikan secara inklusif dan khusus; (2) mempunyai kesamaan kesempatan untuk menjadi pendidik atau tenaga kependidikan pada satuan pendidikan di semua jenis, jalur, dan jenjang pendidikan; (3) mempunyai kesamaan kesempatan sebagai penyelenggara pendidikan yang bermutu pada satuan pendidikan di semua jenis, jalur, dan jenjang pendidikan; dan (4) mendapatkan akomodasi yang Layak sebagai peserta didik. Lebih lanjut Pasal 40 ayat (2) UU No. 8 Tahun 2016 menentukan bahwa hak pendidikan bagi penyandang disabilitas dilaksanakan dalam sistem pendidikan nasional melalui pendidikan inklusif dan pendidikan khusus (Afifah \& Hadi, 2018).

Pada rana pendidikan untuk kelompok disabilitas Kota ambon sudah menerapkan sekolah inklusif sesuai dengan Peraturan Walikota Ambon Nomor 26 Tahun 2014 tentang Penyelenggaraan Pendidikan Inklusif di Kota Ambon akan tetapi adanya hambatanhambatan seperti kurangnya tenaga guru yang memiliki keahlian khusus dari latar belakang pendidikan inklusif. Makin minimnya pemahaman kepala sekolah untuk melaksanakan program bagi anak tentang berkebutuhan khusus, kurangnya pemahaman masyarakat tentang pelayanan inklusif bagi anak yang berkebutuhan khusus, sehingga adanya orang tua yang enggan untuk anaknya mendapat pendidikan.

Hal tersebut diperkuat dengan hasil observasi dan wawancara dengan guru dan kepala sekolah diketahui bahwa indikasi penyelenggaraan pendidikan inklusif di Kota Ambon belum sesuai dengan apa yang diharapkan. Hal ini disebabkan oleh beberapa faktor antara lain: (1) anak- anak di sekolah pada umumnya belum bisa menerima atas kehadiran anak berkebutuhan khusus (ABK) untuk belajar bersama di kelas reguler, dan di pandangmereka hanya menghambat proses pembelajaran; (2) belum siapnya sekolah reguler dalam menyelenggarakan pendidikan inklusif dengan kondisi tersebutmembuat sekolah menolak anak yang berkebutuhan khusus atau tidak dapat diterima di sekolah tersebut; (3) masih rendahnya pengetahuan guru tentangpendidikan inklusif dan ABK dimana guru beranggapan bahwa pendidikan inklusif adalah sekedar menerima ABK di sekolah reguler; (4) pelaksanaan pembelajaran masih secara klasikal belum mengakomodasi kebutuhan ABK;(5) masih terdapat keterbatasan kesiapan sumber daya dalam hal ini belum adanya Guru Pendamping Khusus pada sekolah penyelenggaran inklusif.

Pada kompetensi inilah penyandang disabilitas memerlukan perhatian khusus dikarenakan kewajiban pemerintah dalam menjamin dan melindungi keberlangsungan kesejahteraan hidup warga negaranya, di dalam dunia ketenagakerjaan, persaingan kedudukan dan hak secara adil baru diperoleh dengan kesetaraan tingkat pendidikan yang ditempuh.

Penyandang disabilitas masih mendapatkan perlakuan yang tidak adil di dunia pendidikan seperti masih banyaknya penolakan peserta didik di sekolah reguler, hanya berhak menempuh pendidikan di sekolah khusus (sekolah luar biasa), pada sekolah khusus di samping sekolah umum yang menerapkan sekolah inklusif bagi kelompok disabilitas, sekolah khusus pun penunjang pembelajaran untuk anak berkebutuhan khusus 
belum memadai. Contoh sampel data pada SLB Negeri Batu Merah sesuai dengan data dan wawancara dari kepala sekolah antara lain:

1. Kurangnya buku penunjang pada mata pelajaran masing-masing jurusan;

2. Biaya pendidikan belum mencukupi dalam menunjang kegiatan program;

3. Kurangnya alat-alat terapi dari semua jurusan;

4. Belum adanya kesadaran masyarakat terhadap pendidikan luar biasa khususnya di Maluku;

5. Kurangnya tersedianya peralatan pengembangan diri yang mandiri;

6. Penambahan ruang penunjang program berkebutuhan khusus, misalnya ruang audiometer, ruang terapi/ fisioterapi pada semua jurusan.

Kurangnya sarana penunjang dibidang pendidikan untuk anak penyandang disabilitas. Hal ini berdampak pada kompetensi untuk bersaing dengan yang lain dibidang ketenagakerjaan. Dimana pada era masyarakat sekarang ini dibutuhkan warga negara yang memiliki tiga komponen penting yaitu civic knowledge (pengetahuan kewarganegaraan), civic skills (keterampilan kewarganegaraan), civic disposition (watak kewarganegaraan) (Branson dalam Budimansyah \& Suryadi, 2008, hal. 23).

\section{METODE PENELITIAN}

Penelitian ini menggunakan metode kualitatif. Metode penelitian kualitatif sering disebut dengan metode penelitian naturalistic dengan metode ini, permasalahan yang terjadi di lapangan akan mampu dikupas sedetail- detailnya (Nurgiansah, 2020). Model studi kasus digunakan dalam melaksanakan penelitian ini, sebab masalah penelitian terfokus untuk menemukan faktor kendala pemenuhan hak pendidikan disabilitas di kota Ambon

Penggunaan pendekatan penelitian kualitatif dengan studi kasus dalampenelitian ini dimaksudkan untuk mengetahui kondisi yang objektif dan mendalam tentang fokus penelitian. Studi kasus merupakan penelitian yang didalamnya menyelidiki program, peristiwa, aktivitas, proses secara cermat tentang latar belakang, sifat dan karakter yang khas dari kasus tersebut (Creswell, 2010; Nazir, 2011).

\section{HASIL DAN PEMBAHASAN}

Hasil penelitian ini mengungkapkan bahwa ada dua faktor penghambat dalam pemenuhan hak pendidikan penyandang disabilitas di Kota Ambon Provinsi Maluku. Pertama, faktor internal dan kedua, faktor eksternal. Pada faktor internal terkendala upaya pemenuhan hak pendidikan untuk anak penyandang disabilitas yaitu orang tua disabilitas itu sendiri. Orang tua tidak mau mendaftarkan anak mereka ke sekolah dengan alasan sibuk bekerja sehingga tidak bisa antar jemput anak ke sekolah, yang lebih mengejutkan lagi orang tua tidak mau menyekolahkan anak mereka karena orang tua merasa malu dengan kondisi anak. Anak yang memiliki kecacatan menurut perspektif orang tua merupakan aib bagi keluarga. Sehingga memilih diam di rumah ketimbang harus ke sekolah.

Hasil temuan diatas bila dikaji dari sudut pandang kewajiban maka terlihat orang tua tidak memperdulikan pendidikan anak. Pada dasarnya pendidikan anak menjadi 
tanggung jawab orang tua sebagai sentral pendidikan untuk anak yang paling penting dan menentukan. Artinya sebagai orang tua masa depan anak menjadi prioritas, anak dengan kebutuhan khusus sangat membutuhkan perhatian yang ekstra. Sebagai orang tua atau keluarga bertanggungjawab dalam memberikan semangat serta motivasi untuk kelangsungan hidupnya di masa akan datang. Menurut Novita, Amirullah, \& Ruslan (2016, hal. 13) bahwa orang tua merupakan kunci motivasi dan keberhasilan studi anak tidak ada pihak yang akan dapat menggantikan peran orang tua dengan seutuhnya, peran orang tua adalah faktor pendukung dalam memotivasi belajar dan menunjang keberhasilan studi anak.

Menurut Hewett \& Taylor (1968) penanganan dan pelayanan orang tua terhadap anak berkebutuhan khusus adalah sebagai berikut:

1 Sebagai pendamping utama (as aids), yaitu sebagai pendamping utama yang dalam membantu tercapainya tujuan layanan penanganan dan pendidikan anak.

2 Sebagai advokat (as advocates), yang mengerti, mengusahakan, dan menjaga hak anak dalam kesempatan mendapat layanan pendidikan sesuai dengan karakteristik khususnya.

3 Sebagai sumber (as resources), menjadi sumber data yang lengkap dan benar mengenai diri anak dalam usaha intervensi perilaku anak.

4 Sebagai guru (as teacher), berperan menjadi pendidik bagi anak dalam kehidupan sehari-hari di luar jam sekolah.

5 Sebagai diagnostisian (diagnosticians) penentu karakteristik dan jenis kebutuhan khusus dan berkemampuan melakukan treatment, terutama di luar jam sekolah.

Secara konstitusi di Indonesia. peran keluarga dalam pendidikan lebih ditegaskan lagi dalam Pasal 1 dan Pasal 7 UU Sisdiknas. Pasal 1 Ayat (23) dinyatakan bahwa sumber daya pendidikan adalah segala sesuatu yang dipergunakan dalam penyelenggaraan pendidikan yang meliputi tenaga kependidikan, masyarakat, dana, sarana, dan prasarana. Kata masyarakat dalam pasal ini, didalamnya adalah keluarga baik terlibat langsung maupun tidak langsung dalam penyelenggaraan pendidikan. Lebih lanjut pada Pasal 7 Ayat (1) menyebutkan orang tua berhak berperan serta dalam memilih satuan pendidikan dan memperoleh informasi tentang perkembangan pendidikan anaknya. Lebih lanjut Pasal 7 Ayat (2) menyebutkan bahwa orang tua dari anak usia wajib belajar berkewajiban memberikan pendidikan dasar kepada anaknya. Dalam pasal ini jelas bahwa, keluarga dalam hal ini orang tua tidak dapat lepas dari tanggung jawab pelaksanaan pendidikan baik dalam persiapan, proses, dan pelaksanaan dalam berbagai aspek yang dibutuhkan anak penyandang disabilitas untuk menempuh pendidikan.

Orang tua yang kurang peduli serta memiliki pandangan bahwasanya anak penyandang disabilitas adalah aib keluarga merupakan pemahaman yang dangkal terhadap anak yang memiliki keterbatasan. Hasil penelitian menunjukan bahwa Faktor pengetahuan orang tua sangat mempengaruhi hal ini diperkuat dengan informan yang peneliti datangi rata-rata mereka beranggapan bahwa "untuk apa pendidikan bagi anak yang memiliki keterbatasan, nanti juga tidak bisa bersaing dengan siswa normal". Seharusnya orang tua dari anak berkebutuhan khusus memiliki peranan yang besar, baik dalam pengambilan keputusan untuk pendidikan sampai pada dukungan kepada anak. Dukungan orang tua adalah keterlibatan orang tua dalam berbagai bentuk termasuk mengasuh di dalam rumah, menciptakan situasi yang aman dan stabil, dan model pengasuhan yang tepat. Seorang anak berkebutuhan khusus dapat mencapai potensinya 
secara maksimal apabila mendapat dukungan penuh dari orang tuanya. Dukungan dari ibu dapat memunculkan perasaan berharga pada anak, sementara dukungan dari ayah dapat mengembangkan kompetensi anak (Wardani, Hernawati, \& Somad, 2009).

Analisis diatas terlihat jelas upaya pemenuhan hak pendidikan bagi penyandang disabilitas di Kota Ambon terhambat akibat dari orang tua belum memiliki kesadaran untuk menyekolahkan anaknya. Sudah tentu pemerintah Kota Ambon dalam hal ini dinas terkait dan sekolah-sekolah agar giat melakukan sosialisasi kepada masyarakat melakukan kunjungan ke rumah-rumah atau keluarga-keluarga yang memiliki anak berkebutuhan khusus dan memberikan pemahaman agar keluarga atau orang tua bisa mengerti dan menghilangkan pandangan yang buruk kepada anak yang memiliki kebutuhan khusus.

Pada faktor hambatan selanjutnya yaitu faktor eksternal dimana pada faktor eksternal ini datangnya dari tanggung jawab pemerintah dalam melaksanakan pemenuhan hak penyandang disabilitas di Kota Ambon. dari hasil penelitian terungkap bahwa kendala dalam upaya pemenuhan hak pendidikan antara lain faktor sarana prasarana dan tenaga pendidik. Pertama, Berkaitan dengan kendala sarana prasarana dalam pemenuhan hak pendidikan bagi penyandang disabilitas di Kota Ambon sangatlah memprihatinkan pada sekolah inklusif dan beberapa sekolah SLB menunjukan sekolah yang tidak ramah disabilitas hal itu dibuktikan dengan ketidak adanya sarana aksesibilitas seperti jalan pada lingkungan sekolah dan alat-alat bantu pembelajaran antara lain kurangnya buku penunjang pada mata pelajaran masing-masing jurusan, kurangnya Alat-alat terapi dari semua Jurusan, kurangnya tersedianya peralatan pengembangan diri yang mandiri, dan penambahan ruang penunjang program berkebutuhan khusus, misalnya ruang audiometer, ruang terapi/fisioterapi pada semua jurusan.

Hasil diatas jelas terlihat masih sangat kurangnya sarana dan prasarana pendukung anak penyandang disabilitas dalam menempuh pendidikan pada sekolah-sekolah di Kota Ambon baik inklusif maupun SLB. Menurut Soleh (2016, hal. 205) sarana dan prasarana haruslah mempertimbangkan keamanan dan kenyamanan dikarenakan keterbatasan mobilitas penyandang disabilitas. dalam melakukan pembangunan sarana dan prasarana harus mengacu kepada Peraturan Menteri Pekerjaan Umum Nomor 30/PRT/M/2006 tentang Pedoman Teknis Fasilitas dan Aksesibilitas Pada Bangunan Gedung dan Lingkungan. agar anak penyandang disabilitas pada lingkungan sekolah merasa nyaman guna mewujudkan kesamaan kesempatan untuk penyandang diabiitas di sekolah. Dengan ketidakadanya sudah barang tentu, penyandang disabilitas dalam melakukan aktivitasnya di lingkungan sekolah sangatlah terganggu. Adanya aksesibilitas yang mumpuni secara moral memberikan rasa keadilan bagi anak penyandang disabilitas. Pasal 1 Ayat (8) UU No. 8 Tahun 2016 menyebutkan bahwa aksebilitas adalah kemudahan yang disediakan untuk penyandang disabilitas guna mewujudkan kesamaan kesempatan. Adanya aksesibilitas yang mumpuni maka pemerintah Kota Ambon memberikan kemudahan kepada penyandang disabilitas untuk mendapatkan hak pendidikannya seperti siswa pada umumnya.

Pasal 1 Ayat (23) UU Sisdiknas_dinyatakan bahwa sumber daya pendidikan adalah segala sesuatu yang dipergunakan dalam penyelenggaraan pendidikan yang meliputi tenaga kependidikan, masyarakat, dana, sarana, dan prasarana. Kata sarana prasaran dalam pasal ini, mengandung arti bahwa pemerintah Kota Ambon berkewajiban dalam memfasilitasi sarana dan prasarana penunjang dalam mendapatkan hak pendidikan bagi 
semua anak, penyandang disabilitas pun harus diperlakukan adil dalam mengakses pendidikan.

Berkaitan dengan sarana dan prasarana sesuai dengan analisis diatas terlihat bahwa pemerintah belum fokus ke hal sarana prasarana sesuai hasil penelitian terungkap bahwa pemerintah Kota Ambon masih fokus untuk sosialisasi dan pelatihan guru-guru pendamping khusus untuk anak-anak penyandang disabilitas di Kota Ambon. Keterbatasan sarana dan prasarana berdampak pada kurangnya pelayanan yang diberikan sekolah bagi anak dengan kebutuhan khusus. Masalah utama minimnya sarana dan prasarana yang dimiliki oleh sekolah penyelenggara inklusif dan pendidikan khusus adalah faktor biaya (Yusraini, 2013, hal. 28).

Kedua, Tidak semua guru memiliki latar belakang pendidikan inklusif, sejak dicanangkan Kota Ambon menuju kota inklusif pada tahun 2014 sampai saat ini sangat kekurangan guru yang sesuai dengan kualifikasi pendidikan khusus sesuai data yang peneliti himpun untuk sekolah luar biasa (SLB) dari jumlah keseluruhan guru 82 orang guru yang sesuai dengan kualifikasi pendidikan khusus sebanyak 20 orang guru atau $24,4 \%$ dan 18 atau $21.9 \%$ orang guru mengikuti bimbingan dan pelatihan penanganan anak berkebutuhan khusus selanjutnya pada sekolah inklusif dari jumlah guru total guru pendamping sebanyak 46 guru semuanya merupakan guru mata pelajaran dan guru kelas yang mengikuti pelatihan dalam menangani anak berkebutuhan khusus.

Sesuai dengan hasil observasi di lapangan baik pada sekolah luar biasa (SLB) maupun sekolah inklusif mengeluhkan hal demikian dimana tidak adanya guru yang spesifikasi keahlian dalam membimbing anak sesuai dengan kebutuhan individu anak. Untuk guru pendamping sangat mengalami kesulitan dalam mendampingi anak dengan beberapa jenis kecacatan anak seperti kebutuhan autisme, tunagrahita berat, tunarungu. Guru dengan tidak memiliki keterampilan untuk mengajar siswa dengan berbagai kebutuhan khusus, namun kebijakan telah menuntut mereka untuk menerima keberadaan anak berkebutuhan khusus di kelas. Hal ini akan berpengaruh terhadap penerimaan guru dan perlakuan guru.

Menurut Pavri \& Luftig (dalam Pujaningsih, 2011, hal. 67) Sikap yang ditunjukkan guru tersebut akan mempengaruhi penerimaan anak berkebutuhan khusus oleh temantemannya. Dengan demikian komitmen guru di sekolah inklusi menjadi salah satu faktor yang paling penting dalam keberhasilan atau kegagalan program inklusif selanjutnya menurut bahwa penolakan dari guru dan lemahnya dukungan terhadap anak berkebutuhan khusus disebabkan karena kurangnya pemahaman dan pengetahuan tentang anak dengan kebutuhan khusus. Latar belakang pendidikan yang tidak memberikan bekal kepada guru tentang anak berkebutuhan khusus menjadi penyebab guru di sekolah regular menolak adanya kebijakan sekolah inklusi.

Pendapat dan data penelitian menyangkut dengan kendala tidak semua guru memiliki latar belakang pendidikan inklusif di Kota Ambon bisa diambil benang merahnya bahwasanya program Kota Ambon sebagai kota menuju inklusif yang dicanangkan pada tahun 2014 merupakan suatu kebijakan yang harus menuntut sekolah reguler dengan ketidak adanya guru dengan kualifikasi pendidikan khusus untuk menerima keberadaan anak berkebutuhan khusus di kelas mereka. Hal ini akan berpengaruh terhadap penerimaan guru dan perlakuan guru. Selanjutnya pada sekolah luar biasa (SLB) dengan keterbatasan guru dengan kualifikasi pendidikan sesuai dengan kebutuhan kecacatan siswa bisa mengakibatkan penanganan anak berjalan dengan tidak 
maksimal. Samping itu walaupun pemerintah Kota Ambon mengadakan pelatihan untuk guru-guru pendamping untuk menangani anak berkebutuhan khusus akan tetapi masih ada keluhan yang disampaikan oleh guru-guru pendamping khusus yang berada pada sekolah inklusif.

Tenaga pendidik (guru) berdasarkan Pasal 10 Ayat (1) Undang-Undang Republik Indonesia Nomor 14 Tahun 2005 tentang Guru dan Dosen mempunyai empat kompetensi, yaitu kompetensi pedagogik, kompetensi profesional, kompetensi kepribadian dan kompetensi sosial yang diperoleh melalui pendidikan profesi. Empat kompetensi di atas hanya bisa dihasilkan melalui penyelenggaraan pendidikan yang bermutu. Oleh karena itu, tenaga pendidik guru mempunyai peran, fungsi, dan kedudukan yang sangat strategis. Hal ini berorientasi bahwa dalam penyelenggaraan pendidikan berbasis kompetensi, tenaga pendidik (guru) mempunyai peranan yang sangat penting. Oleh karenanya tenaga pendidik guru juga sebagai salah satu komponen dalam kegiatan belajar mengajar memiliki posisi yang sangat menentukan keberhasilan pembelajaran, karena fungsi utama tenaga pendidik guru adalah merancang, melaksanakan, dan mengevaluasi pembelajaran.

Dengan demikian mutu tenaga pendidik guru mempunyai peranan dan kunci dalam keseluruhan proses pendidikan. Dalam hal ini kekuatan dan mutu pendidikan suatu negara dapat dinilai dengan mempergunakan faktor mutu tenaga pendidik guru sebagai salah satu induk utama. Itulah sebabnya antara lain mengapa mutu tenaga pendidik guru merupakan faktor yang mutlak di dalam pembelajaran. Makin sungguh-sungguh sebuah pemerintahan untuk membangun negerinya, makin menjadi penting kedudukan mutu tenaga pendidik guru.

Upaya meningkatkan profesionalisme guru pendamping khusus dari segi aspek pendidikan telah dilakukan pemerintah dengan dikeluarkannya Peraturan Pemerintah Republik Indonesia Nomor 72 Tahun 1991 tentang Pendidikan Luar Biasa. Pasal 20 Ayat (2) PP No. 72 Tahun 1991 menyebutkan bahwa "tenaga kependidikan pada satuan pendidikan luar biasa merupakan tenaga kependidikan yang memiliki kualifikasi khusus sebagai guru pada satuan pendidikan luar biasa". Kemudian diperjelas lebih lanjut dalam Pasal 28 Ayat (2) Peraturan Pemerintah Republik Indonesia Nomor 19 Tahun 2005 Tentang Standar Nasional Pendidikan yang mengamanatkan bahwa "kualifikasi akademis adalah tingkat pendidikan minimal yang harus dipenuhi oleh seorang pendidik yang dibuktikan dengan ijazah dan atau sertifikat keahlian yang relevan sesuai ketentuan perundang-undangan.

Dari analisis diatas terlihat bahwa seorang guru pendidikan luar biasa harus memiliki kualifikasi khusus sesuai guru pada satuan pendidikan luar biasa. Hal ini dikarenakan memberikan pendidikan bagai anak-anak berkebutuhan khusus merupakan tantangan yang sangat berat. Karena berkaitan dengan semua komponen-komponen pembelajaran bagai berkebutuhan khusus yang benar-benar harus dipersiapkan dengan baik. Tanggung jawab pendidikan anak-anak berkebutuhan khusus di sekolah terletak di tangan pendidik. Itu sebabnya para pendidik harus dididik dalam profesi kependidikan, agar memiliki kompetensi yang diperlukan untuk melaksanakan tugas dan fungsinya secara efisien dan efektif (Hamalik, 2001, hal. 6).

Pentingnya fungsi guru sebagai pengajar, pendidik dan pembimbing di sekolah untuk itu menjadi pekerjaan rumah bagi pemerintah Kota Ambon dalam upaya membuka jurusan pendidikan khusus pada perguruan tinggi di Kota Ambon dikarenakan salah satu indikator ketidak adanya guru dengan kualifikasi pendidikan khusus adalah belum 
tersedianya jurusan pendidikan khusus di perguruan tinggi di provinsi Maluku hal ini sesuai dengan data di lapangan sesuai hasil observasi peneliti di beberapa kampus yang ada di Pulau Ambon antaranya Universitas Pattimura Ambon (UNPATTI), Universitas Darussalam Ambon (Unidar), Institusi Agama Islam Negeri Maluku (IAIN) dan Universitas Kristen Maluku (UKIM) belum ada satu pun universitas tersebut yang membuka jurusan pendidikan khusus. hal ini sangat berdampak terhadap kompetensi guru di sekolah yang berdampak terhadap pelayanan kepada siswa.

\section{SIMPULAN}

Kendala implementasi hak pendidikan untuk penyandang disabilitas di Kota Ambon yaitu:

1. faktor orang tua terkait dengan kesadaran pentingnya pendidikan bagi anak mereka denganberbagai alasan yang ditemui yaitu, faktor pendidikan orang tua, orang tua merasa malu dengan kondisi anak menjadi suatu Aib bagi keluarga, kesibukan dalam bekerja, dan faktor akses ke sekolah yang jauh. Maka berimplikasi terhadap anak penyandang disabilitas tidak bersekolah atau mengenyam pendidikan. Agar orang tua mengubah cara berfikir bahwasanya anak penyandang disabilitas itu adalah aib bagi keluarga, akan tetapi mulailah berpikir positif bahwasanya banyak anak diluar yang memiliki keterbatasan akan tetapi bisa hidup mandiri tanpa ketergantungan dari orang tua, dengan pendidikan maka anak tersebut bisa meningkatkan kemampuan dirinya;

2. kendala sarana prasarana dimana pada sekolah inklusif maupun sekolah luarbiasa (SLB) di Kota Ambon untuk sarana prasarana penunjang kebutuhan penyandang disabilitas di sekolah masih sangat kurang dikarenakan penyelenggara sekolah inklusi dan sekolah khusus memang membutuhkan sarana dan prasarana yang banyak, dikarenakan anak penyandang disabilitas memiliki kebutuhan individual masingmasing. Misalnya kelas untuk bimbingan khusus, jalan khusus anak tuna daksa, alat bantu pendengaran untuk anak tuna rungu, buku braille untuk anak tunanetra, dan sebagainya. Dengan keterbatasan sarana prasarana penunjang pembelajaran sangat berimplikasi terjadi kendala dalam pembelajaran bagi anak penyandang disabilitas dengan kebutuhan Individual anak masing-masing. Untuk itu pemerintah harus menyediakan sarana dan prasarana untuk mendukung pembelajaran bagi anak-anak disabilitas baik yang berada pada sekolah inklusif maupun SLB;

3. kendala guru pendamping khusus yang kualifikasi pendidikannya bukan pendidikan khusus. Hal akan berimplikasi terhadap kompetensi pedagogik dan kompetensi profesional guru tersebut dalam melangsungkan aktivitas pembelajaran di lingkungan sekolah. Agar lebih memperhatikan lagi anak-anak yang berkebutuhan khusus di sekolah-sekolah formal di Kota Ambon dengan cara memberikan pelatihan atau sejenisnya dalam meningkatkan kompetensi pedagogik dan kompetensi profesional guru pendamping khusus mengingat latar belakang guru pendamping khusus hampir sebagian besar yaitu $82.7 \%$ bukanlah kualifikasi pendidikan khusus.

\section{UCAPAN TERIMA KASIH}

Terima kasih penulis ucapkan karena dapat menyelesaikan dan mempublikasikan tulisan ini. Penulis menyadari dalam penelitian dan penulisan jurnal ini tidak terlepas dari bantuan dari berbagai pihak. Untuk itu sebagai ungkapan terimakasih kepada pemerintah 
kota Ambon, Sekolah inklusif dan SLB di kota Ambon yang dengan senang hati memberikan data kepada peneliti. Kiranya Allah SWT membalas kebaikan dan niat baik Bapak/Ibu.

\section{DAFTAR PUSTAKA}

Afifah, W., \& Hadi, S. (2018). Hak Pendidikan Penyandang Disabilitas Di Jawa Timur. DiH: Jurnal Ilmu Hukum, 14(2), 85-101. https://doi.org/10.30996/dih.v0i0.1793

Basuki, U. (2012). Perlindungan HAM dalam Negara Hukum Indonesia: Studi Ratifikasi Konvensi Hak-hak Disabilitas (Convention on The Rights of Persons with Disabilities). Sosio-Religia, 10(1), 17-34.

Budimansyah, D., \& Suryadi, K. (2008). PKn dan Masyarakat Multikultural. Bandung: Program Studi Pendidikan Kewarganegaraan, Sekolah Pascasarjana, Universitas Pendidikan Indonesia.

Creswell, J. W. (2010). Research Design: Pendekatan Kualitatif, Kuantitatif, dan Mixed. Yogyakarta: Pustaka Pelajar.

Hamalik, O. (2001). Proses Belajar Mengajar. Jakarta: PT. Bumi Aksara.

Hewett, F. M., \& Taylor, F. D. (1968). The Emotionally Child in The Classroom Disorders. USA: Ellyn and Bacon, Inc.

Itasari, E. R. R. (2020). Perlindungan Hukum Terhadap Penyandang Disabilitas Di Kalimantan Barat. Journal.Unnes.Ac.Id, 32(1), 70-82. https://doi.org/10.15294/integralistik.v32i2.25742

Nazir, M. (2011). Metode Penelitian. Bogor: Penerbit Ghalia Indonesia.

Novita, D., Amirullah, \& Ruslan. (2016). Peran Orang Tua Dalam Meningkatkan Perkembangan Anak Usia Dini di Desa Air Pinang Kecamatan Simeulue Timur. Jurnal Ilmiah Mahasiswa Pendidikan Kawarganegaraan Unsyiah, 1(1), 22-30.

Nurgiansah, T. H. (2020). Fenomena Prostitusi Online di Kota Yogyakarta dalam Perspektif Nilai Kemanusiaan Yang Adil dan Beradab. Jurnal Kewarganegaraan, 17(1), 27. https://doi.org/10.24114/jk.v17i1.14208

Pawestri, A. (2017). Hak Penyandang Disabilitas dalam Perspektif HAM Internasional dan Nasional. Era Hukum, 2(1), 1-19.

Peraturan Pemerintah Republik Indonesia Nomor 19 Tahun 2005 tentang Standar Nasional Pendidikan.

Peraturan Pemerintah Republik Indonesia Nomor 72 Tahun 1991 tentang Pendidikan Luar Biasa.

Peraturan Walikota Ambon Nomor 26 Tahun 2014 tentang Penyelenggaraan Pendidikan Inklusif.

Pujaningsih. (2011). Redesain Pendidikan Guru untuk Mendukung Pendidikan Inklusif. Yogyakarta: Universitas Negeri Yogyakarta. 
Santoso, M. B., \& Apsari, N. C. (2017). Pergeseran Paradigma dalam Disabilitas. Intermestic: Journal of International Studies, 1(2), 166. https://doi.org/10.24198/intermestic.v1n2.6

Soleh, A. (2016). Aksesibilitas Penyandang Disabilitas terhadap Perguruan Tinggi; Studi Kasus di Empat Perguruan Tinggi Negeri di Yogyakarta. Yogyakarta: LKIS Pelangi Aksara.

Undang-Undang Dasar Negara Kesatuan Republik Indonesia Tahun 1945.

Undang-Undang Republik Indonesia Nomor 14 Tahun 2005 tentang Guru dan Dosen.

Undang-Undang Republik Indonesia Nomor 20 Tahun 2003 tentang Sistem Pendidikan Nasional.

Undang-Undang Republik Indonesia Nomor 8 Tahun 2016 tentang Penyandang Disabilias.

Wardani, I. G. A. K., Hernawati, T., \& Somad, P. (2009). Pengantar Pendidikan Luar Biasa. Jakarta: Universitas Terbuka.

Widinarsih, D. (2017). Inklusi Penyandang Disabilitas di Indonesia. Jurnal Refleksi Hukum, $1,1-4$.

Yusraini. (2013). Kebijakan Pemerintah Terhadap Inklusif. Jurnal Media Akademika, $28(1)$. 